\title{
КРУГЛЫЙ СТОЛ
}

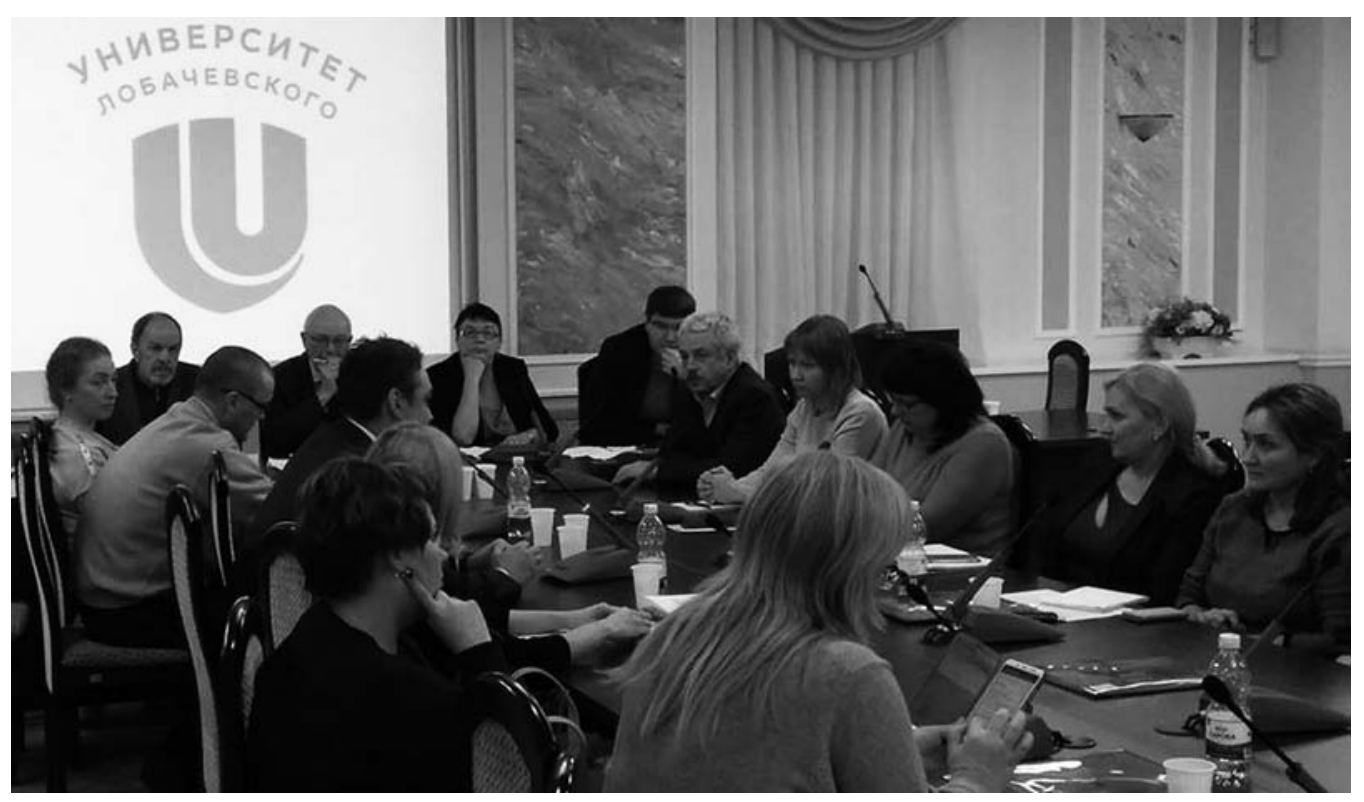

\section{Новая модель российской аспирантуры: проблемы и перспективы}

16 нолбрл 2018 года В Начиональном исследовательском Нижегородском государственном университете им. Н.И. Аобачевского в рамках Программы повышения квалификачии состоялся кругльй стол, организованный Институтом аспирантуры и докторантуры ННГУ совместно с редколлегией журнала «Высшее образование в России» на тему «Новая модель российской аспирантуры: проблемы и перспективы развития». Програлма реализована в соответствии с «дорожной картой» Проекта повышения конкурентоспособности ННГУ среди ведуших мировых научно-образовательных центров (проект «5-100») на 2018 год. В мероприятии приняли участие 48 административно-управленческих и научно-педагогических работников из 24 городов, представляюших 37 университетов и научньх организачий Российкой Федерачии ( в том числе НИТУ МИСиС, Высшую школу экономики, ННГУ, Томский политехнический университет, Самарский начиональньй исследовательский университет им. академика С.П. Королёва, РЭУ им. Г.В. Плеханова, Белгородский начиональньй исследовательский университет, Мордовский государственньй университет им. Н.П. Огарёва, Тюменский начиональный исследовательский университет и др.).

В обсуждении ключевьх вопросов современной российской аспирантуры наиболее активное участие приняли: Бедньй Борис Ильич (директор Института аспирантурь и докторантурьи, ННГУ), Сапунов Михаил Борисович (главньй редактор журнала «Высшее образование в России ), Игнатов Андрей Сергеевич (директорЦентра подготовки кадров высшей квалификачии, МИСиС), Кузенков Олег Анатольевич (заместитель директора Института информачионных технологий, математики и механики, ННГУ), Терентьев Евгений Андреевич (старший научный сотрудник Центра сочиологии высшего образования, ВШЭ), Еськина Елена Владимировна (начальник отдела аспирантурь, Самарский начиональньй 
исследовательский университет), Алтлова Ксения Амитриевна (профессор, ННГУ), Агеева Ольга Николаевна (начальник Управления подготовки кадров высшей квалификачии, Мордовский государственньй университет им. Н.П. Огарёва), Муратова Евгения Ивановна (начальник Управления аспирантуры и докторантурь, Тамбовский государственньй технический университет), Миронос Алексей Андреевич (заведуюший кафедрой, ННГУ), Рьюбаков Николай Валерьевич (начальник отдела, ННГУ).

Ведушие круглого стола: Б.И. Бедный, М.Б. Сапуноһ.

Ключевые слова: аспирантура, научно-педагогчческие работники, подготовка кадров высшей квалификачии, диссертачия, образовательные стандарты аспирантурь, образовательные программы аспирантуры, государственная итоговая аттестация аспирантов

Аля циитирования: Бедный Б.И., Сапунов М.Б. и др. Новая модель российской аспирантуры: проблемы и перспективы (круглый стол) // Высшее образование в России. 2019. Т. 28. № 1. C. 130-146.

DOI: https://doi.org/10.31992/0869-3617-2019-28-1-130-146

Б.И. Бедный: Уважаемые коллеги! В финальной части нашей программы повышения квалификации в формате круглого стола предусмотрено обсуждение вопросов, касающихся состояния дел в современной российской аспирантуре: её цели, задачи, функционал, организация обучения и научной работы аспирантов. При обсуждении наболевших вопросов хотелось бы сконцентрировать внимание на поиске реалистичных направлений развития, моделей и механизмов совершенствования той системы аспирантского образования, в рамках которой мы сегодня работаем. Попытаюсь сформулировать некоторые вопросы и проблемы, которые в контексте нашего обсуждения представляются особенно значимыми. Обучаюшая аспирантура - это проблема или благо? Аспирантура и рынок труда. (Эмпирические данные говорят о том, что приблизительно половина выпускников аспирантуры уходит из академической сферы. Аолжно ли это отражаться на образовательном процессе? Надо ли вносить изменения в программы аспирантской подготовки, если мы уверены, что учёными и вузовскими преподавателями будут не более $50 \%$ выпускников программы?) Аспирантура и диссертащия. (Как повлияла новая модель аспирантуры на защиты кандидатских диссертаций выпускниками аспирантуры?) Как оптимизировать и надлежашим образом обустроить адресную подготовку высококвалифичированных кадров для науки и высшей школье? Как надо готовить спечииалистов высшей квалификачии для индустрии и бизнеса? Как оптимизировать формирование и развитие преподавательских компетениий у аспиранта, совместив это с его научной работой и подготовкой кандидатской диссертачии?

Конечно, эти вопросы - лишь наброски плана нашего обсуждения. У каждого из вас могут быть свои кейсы и предложения. Коллеги, проблемам современной российской аспирантуры в последние годы особое внимание уделяет журнал «Высшее образование в России». В нём постоянно публикуются статьи на эту тему ведущих российских экспертов, причём в равной мере представлены и аналитические, и эмпирические работы, основанные на современных социологических материалах. Поэтому мне хотелось бы попросить начать наш разговор главного редактора журнала. Вам слово, Михаил Борисович.

M.Б. Сапунов: Насколько мне известно, в нашей Программе повышения квалификации была предварительная заочная часть, и участникам рассылались материалы по актуальным проблемам аспирантуры. Мне кажется, что эти материалы тоже могут быть 
основой нашего разговора. В ближайшем номере журнала «Высшее образование в России» будет опубликована статья наших коллег из Ассоциации классических университетов России «Аспирантура как уровень высшего образования: состояние, проблемы, возможные решения». Статья интересна тем, что в ней представлена позиция АКУР по некоторым вопросам, поставленным Борисом Ильичом. Я убежден в том, что тема этого круглого стола «горячая», и вполне возможно, что предстоящее обсуждение может оказаться полезным не только для присутствующих. Надо, чтобы итоги нашей работы были представлены научно-педагогическому сообществу, чтобы как можно больше коллег узнали, что мы провели очень важное и полезное мероприятие. Журнал опубликует материалы круглого стола в первом номере будущего года.

Б.И. Беднъй: Кстати, вот ещё одна тема. Аве недели назад в РАН состоялись общественные слушания по вопросу аспирантуры. Обсуждалось предложение по введению двух типов аспирантур: научной и ... научно-педагогической (очень хотелось сказать «... и ненаучной»). Предполагается, что первая (научная) аспирантура будет завершаться защитой диссертации и присуждением учёной степени, а вторая - защитой дипломной работы и присуждением квалификации преподавателя-исследователя (как сейчас). Эта тема тоже может быть предметом нашего обсуждения. Предоставляю слово Андрею Сергеевичу Игнатову.

A.С. Игнатов: Аобрый день, коллеги. Я представляю НИТУ МИСиС. Мы тоже в своей работе пытаемся найти некий оптимальный баланс интересов при подготовке аспирантов. Естественно, сталкиваемся со всеми упомянутыми уже проблемами. В целом мы должны исходить из того, что сегодня вопросы организации аспирантуры решаются вне рамок самой аспирантуры. Они определяются финансовой и кадровой политикой каждой конкретной организации. Это и вопросы научного руководства - вовлечение научных руководителей в работу с аспирантами, и вопросы финансовой мотивации руководителей и аспирантов качественно доводить работу до конца, т.е. до защиты диссертации. Существуют некие общие рамки, которые мы для себя попытались определить и как-то учитывать в своей работе. МИСИС - крупный вуз, мы, как и Нижегородский университет, входим в программу повышения конкурентоспособности «5$100 »$, выполнение которой предусматривает достижение определённых индикаторов, в том числе и по аспирантуре, по её эффективности. Этим обусловлено и «перетекание» контрольных цифр приёма в ведущие вузы, о чем говорил накануне Борис Ильич. Аумаю, этот тренд будет сохраняться. Подготовка кадров в аспирантуре, скорее всего, будет осуществляться ведущими вузами. Представителям аспирантур необходимо понимать, как с этим работать, возможно, кооперироваться с другими вузами и, соответственно, выстраивать свою научно-образовательную политику.

Аля себя мы видим несколько точек роста, на которые должна быть нацелена наша аспирантская политика. Прежде всего, у нас есть пул современных лабораторий, которые созданы в том числе по программе «5-100», их порядка 30. Кроме того, есть три инжиниринговых центра мирового уровня. Поэтому сейчас для нас главная задача - встроить эти подразделения в аспирантскую подготовку. Отмечу, что зарубежные коллеги, которые приезжают к нам реализовывать какие-либо научные проекты, нацелены в первую очередь на научную составляющую и не всегда понимают, что такое аспирантура в российской действительности, к примеру, какие обязательства берёт на себя научный руководитель. Процесс этот достаточно долгий, сложный, но мы постепенно приходим к тому, что этих людей тоже надо вовлекать (их именами в хорошем смысле слова можно торговать для вовлечения сильных, 
талантливых абитуриентов, готовых к подготовке диссертации и получению учёной степени). Следующая вытекающая из этого задача - это увеличение контингента аспирантуры. На сегодня у нас она достаточно компактная - 560 аспирантов очной формы обучения. Есть задачи по её удвоению в ближайшее время. Эту задачу ставит руководство университета и международный научный совет по программе «5-100». Ещё одна, тоже большая, задача (в принципе, мы с ней справились) - это перевод вуза на самостоятельное присуждение учёных степеней. Это отдельный блок работы, которую мы делаем на протяжении текущего года. Она должна позволить существенно сократить сроки рассмотрения диссертаций и увеличить количество защит. Перечисленные механизмы должны дать инструменты для самостоятельного регулирования процессов подготовки и аттестации аспирантов, снижения бюрократической нагрузки и ускорения процесса рассмотрения диссертационных работ. Нужно добиться того, чтобы после итоговой аттестации аспиранта его работа сразу переходила в диссертационный совет, который рассматривает материалы диссертации и оперативно назначает дату защиты.

Б.И. Бедный: Спасибо, Андрей Сергеевич. Есть ли вопросы?

Реплика из аудитории: Не столько вопрос, сколько замечание. Получается тогда, что провинциальные вузы вообще потеряют квалифицированных преподавателей, аспиранты уедут в Москву и к нам уже не вернутся. Мы пошлём хорошего магистранта туда учиться, и всё... Мы и так теряем студентов с высокими баллами ЕГЭ. Вот что с этим будет?

Б.И. Бедный: Вы предлагаете Андрею Сергеевичу решить этот вопрос?

A.С. Игнатов: Ну, я не министр образования, поэтому... вряд ли.

A.A. Миронос: Андрей Сергеевич, Вы затронули очень важную тему. Аействительно, концентрация аспирантской подготовки в

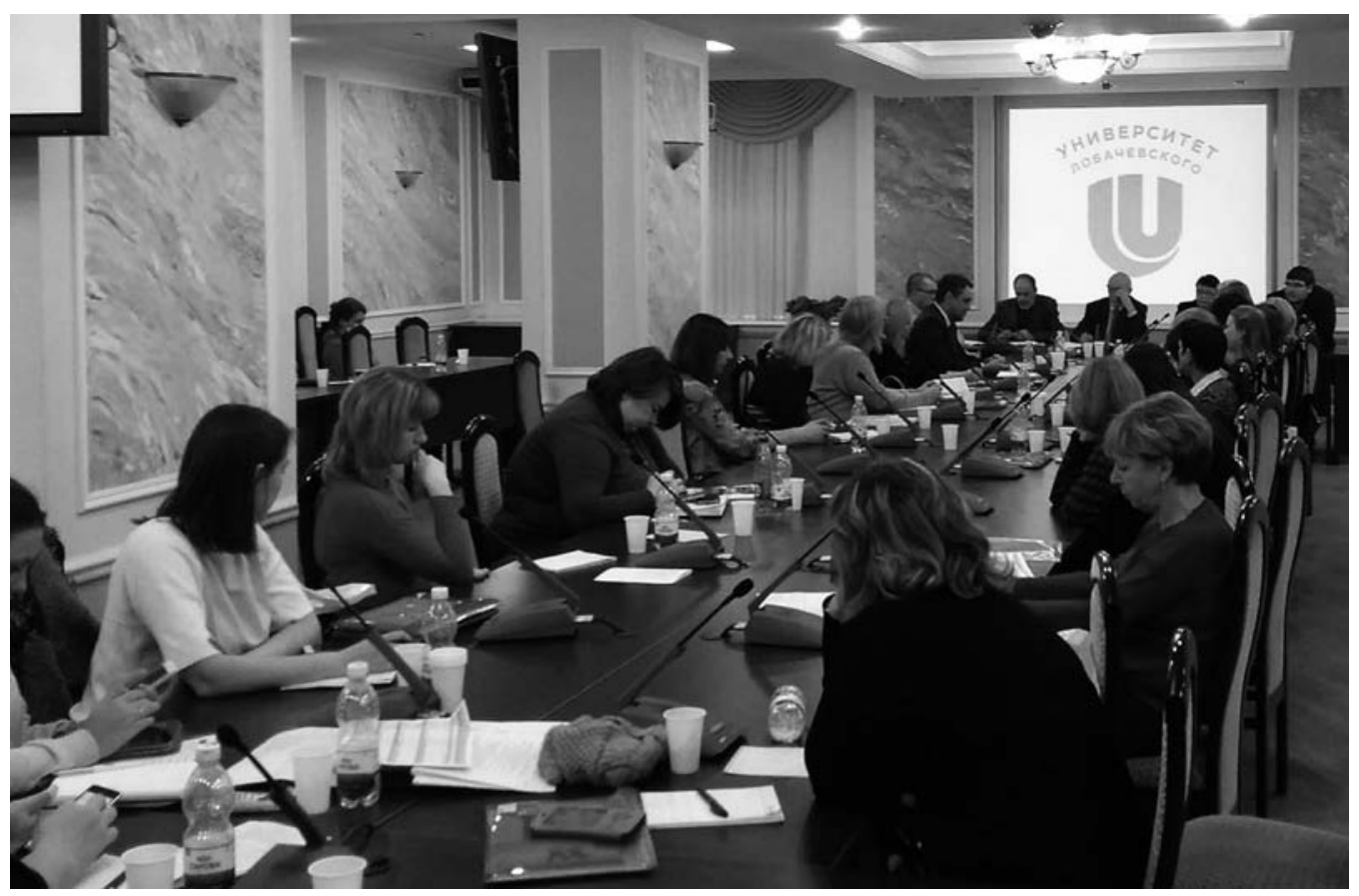


ведущих вузах страны реально осуществляется уже сейчас, и контрольные цифры приёма на бюджет - совершенно понятный и надёжный инструмент движения в этом направлении. В связи с этим возникает очевидный вопрос. Вы задумывались об организационных и, возможно, институциональных средствах, которые бы обеспечили вам возможность удвоения контингента, чтобы как-то «переварить» большое количество аспирантов?

Б.И. Бедный: И, если можно, в дополнение к вопросу Алексея Андреевича. Вы говорили об удвоении числа аспирантов, обучающихся только за счёт средств федерального бюджета, или рассчитываете на расширение внебюджетных форм финансирования аспирантуры?

A.C. Изнатов: Это двойная задача. Идёт увеличение в первую очередь бюджетного приёма, поскольку минимальная стоимость обучения в аспирантуре московских вузов287 тыс. руб. Сложно мотивировать на внебюджет при наличии возможности соискательства за существенно меньшие деньги. Тем более что для потенциального абитуриента, для рынка труда не сформулирован сигнал о том, кто такой выпускник аспирантуры без учёной степени. Но, естественно, вопрос стоит об удвоении и бюджетных, и внебюджетных поступлений. Есть соответствующие документы министерства, которые регулируют соотношение приёма внебюджетных и бюджетных студентов, которые мы должны выполнять. Основной инструмент - это контрольные цифры приёма. У нас приём пока держится на уровне 150 человек в год, но тенденция к увеличению явно просматривается. Что касается возможности «переварить» всё это...Аа, такая возможность есть, поскольку, как я сказал, у нас много международных лабораторий, которые пока не задействованы. Их ресурсом и планируется «переварить» весь этот объём аспирантов, и, как нам подсказывает наш международный научный со- вет, на одного научного руководителя может приходиться 10-15 аспирантов. Это международный опыт.

Б.И. Бедный: Это действительно так, по крайней мере, я знаю несколько зарубежных университетов, где именно такая ситуация, но ведь аспиранты в этом случае своего профессора практически не видят. Там рядом есть постдоки, ассистенты и т.д.

A.C. Игнатов: Аа, в их концепции профессор - это наш заведующий кафедрой, то есть тот, у кого есть доценты, постдоки, аспиранты старших курсов, которые работают с первогодками.

Б.И. Беднъй: Андрей Сергеевич, а как, на Ваш взгляд, может работать модель индустриальной аспирантуры (как известно, у вашего университета обширные связи с промышленностью)? Может быть, уже есть какой-то опыт в этом отношении? Готов ли сейчас бизнес платить за подготовку инженерных кадров высшей квалификации? Имеются ли партнёрские отношения с промышленными предприятиями, в рамках которых привлекаются деньги и люди для обучения аспирантов? Мне представляется, что это очень перспективный ресурс для внебюджетных форм финансирования аспирантуры и адресной подготовки высококвалифицированных специалистов.

A.С. Игнатов: Я бы сказал, что опыт пока достаточно точечный. То есть как таковой системы взаимодействия индустрии и аспирантуры пока нет. Вполне объяснимо, почему бизнес не готов вкладывать деньги в фактически венчурные фонды. Ведь никто на $100 \%$ гарантировать не может, что из любого аспиранта за четыре года получится специалист экстра-класса, который придёт к ним на работу. Бизнес настроен скорее на покупку готовых специалистов с опытом исследовательской работы (статьи, публикации, цитируемость). 
Б.И. Бедный: А если речь идёт о сотрудниках предприятий? Например, имеется талантливый и перспективный в карьерном отношении инженер. Предприятие в нём заинтересовано, поскольку из него можно сделать хорошего руководителя (например, начальника исследовательского или аналитического отдела). Но для этого хорошо бы иметь учёную степень, а подготовить диссертацию можно совместно с университетом при реализации полезного для предприятия научного проекта. Такие схемы не актуальны?

A.С. Игнатов: Такая схема есть, но она действует в рамках института соискательства. Обучающая аспирантура бизнесу пока не нужна.

Б.И. Бедный: Американские и европейские модели организации докторской подготовки также предполагают, что в относительно небольшом числе исследовательских университетов сосредоточен основной контингент аспирантов. Но там имеются финансовые, инфраструктурные и иные ресурсы для поддержки академической мобильности, работают механизмы многоканального финансирования аспирантской подготовки. Как организовать это у нас, когда в провинциальных университетах нет средств для обеспечения целевой аспирантуры, но есть риски, что аспиранты после защиты диссертации не вернутся в свой университет и через несколько лет некому будет учить бакалавров?

A.С. Игнатов: Ну, у меня, честно сказать, ответа на этот вопрос нет. Это вопрос политики в сфере образования и науки, но мне кажется, что такими вот мероприятиями, как наш круглый стол, мы даём некий сигнал, в том числе и контролирующим органам. $\mathrm{K}$ сожалению, в аспирантуре как в «научном предмете» мало кто разбирается, поэтому важность таких мероприятий для меня очевидна. Это определённое мнение профессионального сообщества, которое мы будем транслировать в общении с нашими руководителями, в публикациях, выступлениях. Надо чётко понимать, чего мы сами хотим от аспирантуры, не дожидаясь, что к нам придёт эксперт Рособрнадзора и скажет, что у нас здесь что-то не соответствует ФГОС. Конечно, политика концентрации ресурсов для подготовки кадров высшей квалификации несёт определённые риски, в том числе Аля региональных вузов, но, хотим мы этого или нет, это объективный тренд, и нам надо соответственно выстраивать свою внутреннюю образовательную и научную политику. $\Lambda$ ибо вливаться в новые программы, либо находить какие-то иные точки роста, которые могут потянуть за собой и финансовую поддержку аспирантур.

Б.И. Бедный: То есть надо создавать свои уникальные программы, дабы привлекать магистров.

A.C. Игнатов: Аа, мне видится именно такое решение, и в нашем вузе процессы идут именно в этом ключе.

H.B. Рыбаков: Можно мне сказать несколько слов на эту тему? По поводу региональных и ведущих университетов. Мне кажется, это проблема больше экономическая, и она связана с существованием в нашей стране дотационных регионов и регионовдоноров. Состояние науки и аспирантуры зависит от экономики, и пока у нас сохраняется такое различие регионов по уровню доходов, проблема будет оставаться, и попытка выделить в регионах ведущие университеты - это не самый плохой вариант. Вместе с тем нужно думать и о тех регионах, где нет этих ведущих университетов, но есть люди, которые там должны жить и развивать экономику. А то, что обсуждалось на совещании в $\mathrm{PAH},-$ два типа аспирантур (научная и научно-педагогическая) - это выглядит как попытка отмахнуться от забот региональных вузов. Но, ещё раз повторю, что проблема, конечно же, глубже, в её исто- 
ках - разность экономических потенциалов и уровня жизни людей в регионах.

Б.И. Бедный: Спасибо, Николай Валерьевич. Коллеги, есть ли ещё желающие высказаться по поводу аспирантур в «ведущих» и «ведомых» вузах? Пожалуйста, Елена Владимировна.

E.B. Есъкина: Я полагаю, что аспирантура в региональных вузах обязательно должна оставаться. Это могут быть сетевые программы с ведущими вузами. При этом должна быть нормативная документация, упрощающая оформление таких программ и обеспечивающая аспирантам пребывание в ведущих вузах хотя бы часть аспирантского времени, например возможность полугодовой научной стажировки.

H.B. Рыбаков: Экономическая проблема при этом не снимается, всё равно нужны средства на проживание, на трансфер и проч. То есть вопрос всё равно упирается в финансирование.

E.B. Есъкина: Аа, но если убрать аспирантуры в регионах, тогда у нас вузы быстро «вымрут». Ничего не останется, потому что одна из задач аспирантуры - это подготовка преподавателей высшей школы, их воспитание.

H.B.Pыбаков: Сетевая форма очень интересна, но как это согласовать с требованиями к аккредитации аспирантских программ? Мы обычные-то программы с трудом готовим к аккредитации.

E.B. Eсъкина: Вопрос как раз в том, что должна быть разработана документация, которая бы упростила эти процедуры. Почему никто из нас не стремится связываться с сетевыми программами? Приведу пример. Один из китайских университетов предложил нам совместную сетевую программу: мы вам присылаем двух аспирантов, они у вас учатся один год, а потом на год едут к нам, ну а потом опять к вам. Но это оказалось неосуществимым. Мы их взяли, но с условием отпускать лишь на полгода, не больше, потому что они к аккредитации должны вернуться!

O.H. Azеева: Развитие сетевых аспирантур (или совместных программ) упирается, как это ни банально, в финансовую составляющую. Распределение расходов между участниками сети на практике решается сложно. Какое-то время проект существует, потом, к сожалению, рассыпается. Опыт тех вузов, которые реализуют совместные образовательные программы, показывает, что пока проект финансируется (например, за счёт научных грантов), программа живёт, но как только грант заканчивается, всё исчезает.

Хотелось бы сказать несколько слов по поводу идеи трёхуровневой аккредитации образовательных организаций. Предполагается, что только те вузы, которые пройдут аккредитацию третьего (наивысшего) уровня, будут наделены правом осуществлять подготовку аспирантов. Как представляется, это шаг назад, поскольку получится, что мы обрекаем другие вузы на катастрофическое старение кадров. Там скоро некому будет передавать опыт.

Ещё одна проблема, которая прослеживается в настоящее время, - это мучительная попытка найти ответы на системные вопросы: кого, как и зачем мы готовим? Как мы слышали, сегодня не только провинциальные, но и ведущие вузы испытывают проблемы. Из общения с коллегами следует, что по отдельным направлениям подготовки многие университеты не могут «закрыть» выделенные им контрольные цифры приёма. Зачастую набор осуществляется в два этапа (первая волна, вторая волна), процесс растягивается. Конечно, «фанатики» (в хорошем смысле слова) есть всегда и везде. Это мотивированные ребята, которые несмотря ни на что и вопреки всему хотят учиться, заниматься научными исследованиями. Но на 
что мы их нацеливаем, на что ориентируем? Академическое сообщество весьма консервативно по своему мировосприятию, по установкам, по принципам. Ао сих пор многие субъективно привержены старому формату аспирантуры, по которому обучалось большинство современных учёных. Поэтому государственные стандарты применительно к аспирантуре вызывают у них неприятие: какие ещё стандарты, что это, как это и зачем? Ведь вписать науку в стандарт - это задача сверхсложная, по существу, невыполнимая. Когда мы переходили на собственные стандарты, многие задавали вопрос: а какими профессиональными стандартами вы руководствуетесь? Известен профессиональный стандарт педагога, а стандарт научного работника ещё в проекте, и перспективы его весьма туманны. Есть иные профессиональные стандарты, в которых закреплён 8-й уровень квалификации, но в любом случае профессиональный стандарт констатирует данность, а на будущее, на развитие какихто новых компетенций он вряд ли ориентирован. Вот Борис Ильич затрагивает вопрос о подготовке кадров высшей квалификации не только для образования и науки, но и для бизнеса, для индустрии. По-видимому, мы находимся в тупике, закрепив его формулировкой, что аспирантура - это третий уровень высшего образования. Места для манёвра не остаётся, и получается, что стремились к Болонской системе, а в итоге имеем некий миксовый вариант: «Исследователь, преподаватель-исследователь». Прошу прощения за такое сравнение, но это своего рода «морская свинка», которая не имеет отношения ни к морю, ни к свинкам. Кого, как и зачем готовим - вопросы остаются открытыми. Спасибо.

M.Б. Сапунов: Конечно, название квалификации выпускника аспирантуры явно неудачное, но ясно, что важнейшей задачей аспирантуры всё же является подготовка учёных и вузовских преподавателей. Серьёзные разработки в области организации ис- следовательского образования, оптимального согласования программ магистратуры и аспирантуры выполнены в Нижегородском университете. Попросим коллег вкратце рассказать об этом. Пожалуйста, Олег Анатольевич.

O.A. Кузенков: Обсуждая проблемы исследовательского образования, хотелось бы обратить внимание на то, что для достижения наилучшего результата подготовку научных работников и преподавателей нужно начинать как можно раньше, по крайней мере, ещё в магистратуре. Однако существующие нормы, предписанные ФГОС и другими регламентирующими документами, в ряде аспектов ограничивают возможности сопряжения магистерского и аспирантского обучения. Потенциал магистратуры для формирования научного задела обучающихся и подготовки кандидатской диссертации поэтому в полной мере не используется. Часто наблюдается дублирование дисциплин, формирование сходных компетенций. Одним из возможных путей решения существующих проблем является создание интегрированных программ «Академическая магистратура - аспирантура» в ведущих вузах на основе самостоятельно устанавливаемых образовательных стандартов. Требования к условиям реализации и результатам освоения образовательных программ, предписанные такими стандартами, не могут быть ниже соответствующих требований ФГОС. Однако следует заметить, что при этом вузы могут сами определять структуру образовательной программы. Именно это даёт возможность построить траекторию подготовки будущих исследователей и научно-педагогических работников как двухэтапный процесс, провести оптимизацию и согласование учебных планов магистерской и аспирантской частей программы, т.е. обеспечить непрерывность подготовки на втором и третьем уровнях высшего образования. Нам представляется, что методологическим базисом для разработки интегрирован- 
ных программ является компетентностная модель выпускника, которая может быть создана путём гармонизации компетенций магистратуры и аспирантуры, выделения укрупнённых групп компетенций, которые мы называем «мегакомпетенциями». Наш опыт проектирования подобных программ свидетельствует о том, что в интегрированных программах удалось устранить существующую сегодня перегруженность учебного плана аспирантуры образовательными дисциплинами. Важно отметить, что при использовании самостоятельно устанавливаемых стандартов можно отойти от тех самых 30 зачётных единиц трудоёмкости, отводимых ФГОС в структуре аспирантской программы на образовательные дисциплины и модули, а также и от девяти зачётных единиц базовой части программы, направленных на подготовку и сдачу кандидатских экзаменов.

В собственных образовательных стандартах вузы могут заложить иную структуру образовательной программы как в аспирантуре, так и в магистратуре. Например, в программу магистратуры могут быть введены обязательные дисциплины «История и философия науки» и «Иностранный язык» с повышенными требованиями к результатам их освоения. Они предполагают уровень соответствующих кандидатских экзаменов, а также нацеленность на формирование коммуникативных и мировоззренческо-личностных компетенций, предписанных ФГОС аспирантуры. Это даёт право учитывать зачётные единицы трудоёмкости дисциплин, освоенных в магистратуре, при проектировании индивидуального учебного плана второй (аспирантской) части программы. При такого рода «разгрузке» акцент в аспирантуре делается на исследовательской работе. Образовательная компонента в аспирантуре, конечно, остаётся, но она может быть ограничена набором спецкурсов по выбору, которые направлены на углублённое изучение актуальных научных задач по тематике диссертационной работы и проектов, в которых участвует аспирант. Эти курсы предполагают широкое использование разнообразных форм индивидуальной работы с аспирантами: консультации, собеседования, подготовку рефератов, анализ научной литературы, необходимой для проведения диссертационных исследований. В качестве преподавателей могут привлекаться научные сотрудники аспирантских школ и приглашённые специалисты. Тематика таких курсов определяется тематикой выполняемых научных проектов и меняется вместе с её изменением.

M.Б. Сапунов: Спасибо, Олег Анатольевич. У меня к Вам два вопроса. Как Вы организуете исследовательскую практику, и как Вам удается реализовать заложенный в идеологию высшего образования «компетентностный подход»?

O.А. Кузенков: Исследовательскую практику мы распределяем на весь период обучения по интегрированной программе. В этом случае практика даёт возможность выполнения магистрантами и аспирантами своих должностных обязанностей в научном коллективе, реализующем исследовательский проект. Отмечу, что подобная форма организации практики позволяет решать вопросы финансовой поддержки обучающихся и в конечном счёте - одну из ключевых проблем аспирантуры - закрепление молодёжи в творческом коллективе.

Реализация компетентностного подхода - это вторая проблема, с которой сталкиваются вузы при организации обучения в аспирантуре. Несмотря на то, что сама идея компетентностного подхода ещё не проработана в деталях (об этом свидетельствуют её непрерывное развитие, переходы на новые редакции стандартов, обновление сопутствующих приказов об организации образовательной деятельности), требования ФГОС предписывают внедрение компетентностного подхода, что является обязательным условием для организации образовательной деятельности. Разработчики программ часто 
не понимают ни смысла перехода на новые принципы обучения, ни смысла самих компетенций. Серьёзные трудности появляются при модернизации рабочих программ дисциплин, направленных на формирование предписанных ФГОС компетенций, при разработке фондов оценочных средств и т.д. Особенно остро эта проблема проявляется при подготовке вуза к государственной аккредитации. Подтверждением является тот факт, что эксперты Рособрнадзора при аккредитационной проверке нередко отмечают несоответствие прописанных в аспирантских программах компетенций планируемой профессиональной деятельности выпускников.

При подготовке к государственной аккредитации мы организовали серию обучающих семинаров, направленных на раскрытие принципов ФГОС и методов их реализации в учебном процессе. Кроме того, организованы тренинги, помогающие руководителям аспирантских программ и их помощникам адекватно формулировать набор профессиональных компетенций, отражающих сущность каждой программы, раскрывать содержание компетенций через систему специальных индикаторов-показателей, а также разрабатывать средства оценки степени сформированности заявленных компетенций (проверка проводилась по принятой шкале оценивания через систему критериев-дескрипторов). Отметим, что особое внимание мы уделяли проверке сформированности компетенций при проведении государственной итоговой аттестации (государственного экзамена и научного доклада). Предлагаемые подходы мы отразили в методических рекомендациях, изданных Институтом аспирантуры и докторантуры, и довели до выпускающих кафедр.

M.Б. Сапунов: Поскольку мы заговорили о компетенциях и их проверке в процессе государственной аттестации, хотелось бы в этом контексте обсудить вопрос о преподавательских компетенциях и формах проведения государственного экзамена в аспи- рантуре. Предоставим слово профессору Ксении Амитриевне Аятловой.

K.A. Алтлова: Уважаемые коллеги, вы знаете, что утверждённый министерством порядок проведения государственной итоговой аттестации предусматривает два этапа: государственный экзамен и защиту научного доклада об основных результатах научно-квалификационной работы. Абсолютное большинство специалистов едины в трактовке требований к содержанию и процедуре защиты научно-квалификационной работы. В отношении государственного экзамена (ГЭ) у нас есть широкое поле для интерпретации. Цитирую министерский документ: «Государственный экзамен проводится по одной или нескольким дисциплинам и (или) модулям образовательной программы, результаты освоения которых имеют определяющее значение для профессиональной деятельности выпускников». Таким образом, у вузов и научных организаций появляется свобода в формулировке содержания ГЭ, и каждый вуз решает этот вопрос по-своему. Мы проанализировали программы государственной итоговой аттестации многих вузов и выявили три основных формата проведения ГЭ.

1. Традиционный экзамен («билеты - ответы»), причём содержание экзамена у всех разное. Например, во многих вузах на экзамен выносится специальная дисциплина, и он напоминает экзамен кандидатского минимума. У некоторых вузов экзамен проводится по нескольким предметам (например, «педагогика высшей школы + методология науки» или «методы научных исследований + история и философия науки»). В ряде организаций в программы ГЭ включены вопросы по специальной дисциплине и педагогике. По сути, во всех упомянутых случаях на государственном экзамене дублируется промежуточная аттестация аспирантов по ряду предметов.

2. Традиционный экзамен по педагогике + практическое задание.

3. Экзамен в форме представления (защиты) учебно-методической разработки. 
С нашей точки зрения, традиционный экзамен («билеты - ответы») для итоговой аттестации аспирантов вряд ли целесообразен: ведь он проверяет знания, а ФГОС требуют проверки сформированности компетенций! Компетенции формируются и проверяются только в деятельности. Поэтому второй подход - сочетание традиционного экзамена и выполнения практического задания - представляется нам первым шагом в этом направлении. Полностью же компетенции можно попытаться оценить только в случае выполнения аспирантом реальной задачи, в частности при подготовке и представлении государственной экзаменационной комиссии оригинальной учебно-методической разработки.

Кстати, отмечу, что ещё бо́льшая диверсификация программ итоговой аттестации наблюдается в распределении проверяемых компетенций между экзаменом и научным докладом. \ишь некоторые вузы (например, МГУ, ННГУ) полностью разделили проверку сформированности компетенций: одни компетенции оцениваются на экзамене, другие - на защите научного доклада. В программах многих вузов ряд компетенций проверяется на обеих процедурах ГИА. Кроме того, мы выявили, что многие вузы проверяют все предписанные ФГОС компетенции дважды: и на экзамене, и на защите научной работы. Нам представляется, что проверка всех (или даже части) компетенций дважды (на обоих этапах государственной итоговой аттестации) может создать определённые трудности в работе государственной экзаменационной комиссии.

Все эти соображения привели к тому, что в ННГУ был принят нормативный локальный акт ( «Порядок проведения государственной итоговой аттестации по образовательным программам высшего образования - программам подготовки научно-педагогических кадров»), в котором факультетам и институтам предлагалось проводить государственный экзамен в одной из трёх форм:

- презентация подготовленной учебнометодической разработки по одной из дис- циплин в рамках направления подготовки или научной специальности выпускника;

- открытое лекционное или семинарское занятие для студентов по одной из дисциплин в рамках направления подготовки или научной специальности выпускника;

- публичная лекция по тематике диссертационного исследования.

Большинство факультетов предпочли первую форму - презентацию учебно-методической разработки. В качестве таких разработок могли быть представлены рабочие программы дисциплин, конспекты лекций Аля студентов, программы и методические материалы для проведения семинарских занятий, методические указания к практическим и лабораторным работам, сборники задач и заданий для самостоятельной работы студентов, учебные пособия, электронные обучающие и/или контролирующие пособия, комплекты оценочных средств по дисциплине и др. Форма экзамена определила и набор оцениваемых при его проведении компетенций. Они предельно тесно связаны с профессией преподавателя высшей школы (преподавательские компетенции в основном формируются при освоении дисциплины «Психология и педагогика высшей школы» и в процессе педагогической практики).

Презентация учебно-методической разработки проводится в присутствии членов ГЭК. Предварительно она рассматривается на заседании выпускающей кафедры. Её текст, выписка из протокола заседания кафедры, содержащая её характеристику (актуальность темы, целесообразность внедрения в учебный процесс и др.), отзыв руководителя о прохождении аспирантом педагогической практики направляются в ГЭК. Кроме того, в ГЭК передаются копии сертификатов, Аипломов, удостоверений, свидетельств о прохождении курсов повышения квалификации аспиранта (при их наличии). В качестве оценочных средств ГЭК использует текст учебно-методической разработки, качество презентации, содержание публичной дискуссии по результатам подго- 
товленной разработки, отзыв руководителя педагогической практики. Интересно, что вначале многие аспиранты «ворчали», не слишком радостно воспринимали необходимость разработки новых учебно-методических материалов, опасаясь, что это будет дополнительным отвлечением от научных исследований. Однако в итоге и аспиранты, и их руководители поняли, что предложенная форма во многих отношениях предпочтительнее традиционного экзамена и, главное, даёт реальную пользу выпускникам.

В 2017-2018 гг. государственный экзамен сдавали 169 аспирантов ННГУ. После экзамена и объявления его результатов нам удалось организовать анкетирование многих выпускников (99 человек). В результате обработки данных выяснили, что $29 \%$ респондентов имеют опыт преподавательской деятельности в нашем университете, а $68 \%$ планируют заниматься преподаванием в будущем. Подавляющее большинство выпускников $(97 \%)$ в качестве формы государственного экзамена «проголосовали» за защиту учебно-методических разработок. Таким образом, проведение государственного экзамена в форме защиты учебно-методической разработки, подготовленной на основе научных исследований аспиранта, на наш взгляд, является эффективным инструментом для оценки преподавательских компетенций выпускников аспирантуры.

Б.И. Бедный: Спасибо большое, Ксения Амитриевна. Я вижу, что вопросы к Вам есть. Но, может быть, перенесём обсуждение темы госэкзамена «в кулуары»? В заключение нашей дискуссии мне хотелось бы дать возможность высказать свои соображения о совершенствовании системы подготовки научных кадров Евгению Андреевичу Терентьеву и Евгении Ивановне Муратовой, с которыми у нас была предварительная договорённость о кратких выступлениях.

E.A.Tерентьев: Коллеги, большое спасибо за возможность участвовать в столь на- сыщенной и полезной дискуссии, которая, действительно, вскрывает «болевые точки» современной российской аспирантуры. Мне кажется особенно важным подчеркнуть, что сегодня мы подошли не просто к формулированию проблем - мы услышали некоторые решения, которые уже есть в практике ряда университетов. Обмен такими практиками представляется исключительно ценным в текущих условиях, когда на наших глазах происходят существенные перемены в структуре и содержании аспирантской подготовки, и новые принципы ещё только выкристаллизовываются.

В своём выступлении я бы хотел сделать акцент на следующем обстоятельстве. Вести подобные обсуждения следует доказательно, основываясь на данных. Сегодня почти все дискуссии, которые в большом количестве организуются вокруг вопросов, связанных с развитием аспирантуры, носят зачастую спекулятивный характер, отталкиваются от экспертных мнений, как правило, не подкреплённых эмпирическими исследованиями. Существующая статистика в отношении аспирантуры является скудной и не позволяет ответить на многие из поставленных вопросов, поэтому есть большой запрос на то, чтобы активно разрабатывать отдельную исследовательскую повестку по изучению аспирантского образования. В 2016 г. при поддержке ряда присутствующих здесь коллег, в том числе Бориса Ильича Бедного, мы организовали масштабный опрос в университетах «5-100». Его участниками стали более 2000 аспирантов. Я не буду подробно рассказывать о результатах, которые мы получили, но многие из них были неожиданными и расходились с доминирующими в публичном пространстве мнениями. В частности, мы обнаружили, что у значительной части аспирантов есть запрос именно на образовательную аспирантуру. Это указывает на важность подобных исследований для того, чтобы образовательная политика в области развития аспирантуры носила доказательный характер. 
Практика проведения регулярных социологических опросов аспирантов, научных руководителей и администраторов в сфере аспирантского образования активно развивается в ведущих зарубежных университетах. В качестве одного из примеров можно привести «Survey of Graduate Students and Postdoctorates in Science and Engineering»межуниверситетский опрос аспирантов в ведущих американских инженерных и технических университетах. Аругой пример - общенациональное исследование опыта аспирантов в австралийских университетах - «Postgraduate Research Experience Survey». Многие ведущие университеты также реализуют самостоятельные исследования, по результатам которых принимаются реальные решения в области образовательной политики. K сожалению, в России, насколько мне известно, подобные исследования являются редкостью. В Высшей школе экономики мы проводим ежегодный опрос аспирантов начиная с 2012 г. Однако, конечно, большую ценность представляли бы сравнительные данные по разным университетам. Нам удалось получить такой срез в 2016 г., однако пока дальнейшего развития этот проект не получил. В 2018 г. мы совместно с коллегами из ННГУ организовали интересное исследование научного руководства аспирантами в двух наших университетах, часть результатов которого представили вчера в рамках отдельного доклада. Соответственно, мы призываем вас подключаться к подобным исследовательским инициативам для взаимной пользы и на благо развития аспирантуры в целом.

Аанные, полученные в ходе таких обследований, могут использоваться как на уровне системы образования в целом, так и на уровне организаций. На системном уровне они будут дополнять существующие показатели статистического учёта, а также служить источником информации для анализа и прогнозирования потребности в научных кадрах высшей квалификации. На уровне отдельных организаций результаты обследо- ваний могут использоваться руководством для анализа соответствия ожиданий аспирантов содержанию учебного процесса, для выявления проблем и трудностей, с которыми аспиранты и другие участники образовательного процесса сталкиваются в процессе обучения и подготовки диссертационной работы, для определения эффективности отдельных форм работы с аспирантами, для отслеживания уровня удовлетворённости аспирантов возможностями, предоставляемыми организацией, и других целей. Аанные об удовлетворённости аспирантов обучением могут быть полезны также в качестве дополнительного инструмента оценки качества реализации аспирантских программ. В целом это позволит перейти от спекулятивных рассуждений к доказательным дискуссиям в сфере образовательной политики.

E.И. Муратова: Уважаемые коллеги, этот круглый стол мне кажется особенным. Я участвовала в обсуждениях, организованных редколлегией журнала «Высшее образование в России». На них в основном присутствовала профессура, научные руководители аспирантов. Я участвовала также в круглых столах, которые проводились в Учебном центре подготовки руководителей в г. Пушкине для работников аспирантур. Сейчас у нас здесь смешанный формат, и это очень хорошо.

Начну с того, о чём упомянула в своём выступлении Ольга Николаевна, - с «морской свинки». Ещё на заре проектирования образовательных программ аспирантуры предполагалось, что квалификация «Исследователь» будет присваиваться аспирантам НИИ, а квалификация «Преподаватель-исследователь» предназначена для выпускников вузовских аспирантур. Утверждённую же сегодня квалификацию «Исследователь. Преподаватель-исследователь» можно интерпретировать и так: «Исследователь» относится к предметной научной области, а «Преподаватель-исследователь» - это преподаватель, который может проводить науч- 
ные исследования в области педагогики (по крайней мере, так это можно понять). Так что название присваиваемой квалификации явно неудачное, и с этим надо что-то делать.

Я хотела бы поделиться опытом организации аспирантской подготовки в «среднестатистическом» региональном вузе. В аспирантуре Тамбовского государственного технического университета сейчас обучается 175 аспирантов, в «лучшие времена» было в два раза больше. У нас 21 направление подготовки, 32 образовательные программы, примерно поровну «бюджетников» и «договорников». Четверть аспирантов - иностранные граждане. Таким образом, мы востребованы в международном научно-образовательном сообществе. В ТГТУ действуют восемь диссертационных советов по 17 научным специальностям.

На нашем семинаре за эти два дня рассматривалось очень много актуальных вопросов, но из поля зрения выпала тема управления образовательными программами аспирантуры в вузах, то есть роль администраторов работников управлений, отделов аспирантуры - в этом процессе, видение проблемного поля их глазами. По-видимому, надо попросить социологов из Высшей школы экономики и Нижегородского университета провести опрос работников аспирантур по тем же самым вопросам, которые они задавали научным руководителям и аспирантам. Работники аспирантур видят, где «кокетничают» научные руководители и где лукавят аспиранты. Мы видим этот процесс изнутри, находясь в последние годы «между молотом и наковальней», между проректором по науке и проректором по учебно-методической работе, между научными руководителями и аспирантами, между департаментом государственной политики в сфере высшего образования и департаментом аттестации научно-педагогических кадров. Мне хотелось бы, чтобы мы поговорили о конкретных проблемах, которыми сегодня озабочены администраторы аспирантур - от организации приёма в аспирантуру до постдипломно- го сопровождения выпускников. Я могу на примере нашего университета обозначить реперные точки.

В последние годы в рамках контрольных цифр приёма ТГТУ выделяли порядка 17-18 мест и 3-5 мест для иностранных аспирантов. Чтобы не оставлять за бортом талантливых студентов, мы проводим также целевой приём в аспирантуру сотрудников университета. Что касается предприятий-партнёров, которые могли бы финансировать обучение аспирантов, то, к сожалению, у нас это единичные случаи. Ещё одна важная проблема это уровень поступающих в аспирантуру, наличие или отсутствие научного задела. Мы вынуждены отчасти снижать планку требований для аспирантов, поступающих на договорной основе, и на «внебюджет» берём практически всех, хотя научных руководителей порой приходится уговаривать. Вместе с тем мы идём и в сторону усложнения процедуры вступительных испытаний. Например, с 2019 г. вводим экзамен по высшей математике вместо экзамена по философии для поступающих на направления, относящиеся к техническим наукам, хотя, конечно, есть опасения, что кого-то из наших потенциальных абитуриентов это может отпугнуть.

Основная проблема организации процесса подготовки в современной аспирантуре связана с тем, что практически все аспиранты работают, и если два-три года назад они, объясняя пропуски занятий, говорили извиняющимся тоном, то сейчас просто заявляют: «Я работаю». Решение этой проблемы нам продемонстрировали хозяева мероприятия. Я имею в виду аспирантские школы, интегрированные программы «магистратура - аспирантура». Аналогичные подходы реализуются и у нас в ТГТУ, но в них задействовано не более 15-20\% аспирантов. Аля подавляющего большинства аспирантов приоритетом является работа, а не обучение в аспирантуре. Вторая сторона проблемы перегруженность научных руководителей различными видами учебно-методической и организационно-управленческой работы. 
Многие профессора находятся уже в «полуобморочном» состоянии и отказываются от научного руководства.

На стадии государственной итоговой аттестации приходится сталкиваться ещё с рядом проблем. Трудно убедить в необходимости получения диплома об окончании аспирантуры тех, кто досрочно защитил кандидатскую диссертацию; искдючением являются сотрудники университета, которых мы убеждаем в важности диплома для дальнейшей преподавательской карьеры. Напротив, получивших диплом об окончании аспирантуры бывает трудно убедить в том, что не надо расслабляться, не надо делать перерыв, надо сосредоточиться и довести работу до защиты кандидатской диссертации. И ещё одна проблема - неопределённость постдипломного статуса. Кто они - выпускники аспирантуры между дипломом об окончании аспирантуры и защитой кандидатской диссертации? Они и не обучающиеся, но и не наши сотрудники. Мы, конечно, опекаем своих выпускников, но, по сути, они уже формально не имеют к нам никакого отношения. Особые юридические сложности возникают с иностранными выпускниками аспирантуры. Ао сих пор остаются открытыми и некоторые технические вопросы - по заполнению приложения к диплому, документов, подтверждающих сдачу кандидатских экзаменов, и др. Мы постоянно обмениваемся опытом с коллегами по решению конкретных ситуаций, но хотелось бы иметь более проработанную нормативную базу.

Б.И. Бедный: Спасибо, Евгения Ивановна. Вы подняли большой пласт актуальных проблем. Я бы хотел, чтобы Вы пояснили, почему молодые люди не хотят после аспирантуры поторопиться и защитить диссертацию, если работа почти готова и соответствует требованиям, предъявляемым к кандидатской диссертации. Казалось бы, «точка невозврата» пройдена, надо же этим воспользоваться!
E.И. Муратова: Попробую пояснить на примерах. В 2017 г. примерно половина выпускников аспирантуры помимо диплома получили заключение организации по диссертации с рекомендацией к её защите. После подготовки к представлению научного доклада, оформления научно-квалификационной работы, сопутствующих документов большинство выпускников решили позволить себе отдых. В дальнейшем причины разные: у некоторых изменились планы или семейные обстоятельства, в ряде диссертационных советов уже были сформированы планы защит, некоторые диссертационные советы приостановили свою деятельность.

Б.И. Бедный: На Ваш взгляд, это массовое, статистически значимое явление или все-таки единичные случаи?

E.И. Муратова: Пожалуй, это всё-таки статистически значимое явление. Мы ожидали более короткой траектории между представлением научного доклада и защитой кандидатской диссертации. Знаете, в каких случаях наблюдаются исключения? Если защита диссертации является необходимым индикатором по гранту, если у иностранных аспирантов предусмотрены санкции за отсутствие защиты диссертации.

Б.И. Бедный: Евгения Ивановна, подводя итог, хотелось бы задать ещё один вопрос. Новая модель аспирантуры, так называемая обучающая аспирантура - это проблема или благо?

E.И. Муратова: С точки зрения содержания и объёма образовательной программы обучающая аспирантура, если она правильно реализуется, это благо. С точки зрения бюрократизации, формализации учебного процесса - это проблема.

Б.И. Бедный: Спасибо. Коллеги, кто ещё хочет высказаться на темы, поднятые Евгенией Ивановной? Пожалуйста, Андрей Сергеевич. 
A.C. Игнатов: Краеугольный камень в истории с постдипломной судьбой выпускников - это гранты, которые научные руководители выигрывают и которые могут в том числе быть использованы для софинансирования аспирантских работ. Мне кажется, что вся аспирантура постепенно должна переходить от контрольных цифр приёма к грантам. Потому что в текущей реальности, к сожалению, научный руководитель не несёт серьёзной ответственности, если не доводит своего аспиранта до защиты. И никак на это повлиять нельзя. Необходимость софинансирования со стороны научного руководителя аспирантской работы будет как-то стимулировать этот процесс.

Б.И. Бедный: Андрей Сергеевич, я с Вами по сути согласен. Репутационная ответственность научного руководителя - это важный фактор для повышения эффективности аспирантуры. Если есть гранты, то можно ожидать и защит. Но, к сожалению, Аля гуманитарных наук это пока представляется маловероятным. Как быть аспирантам и научным руководителям, работающим в области философии, филологии, истории, педагогики, юриспруденции и т.д.? Где эти гранты? Конечно, многое зависит от фондов поддержки науки, от средств, которые выделяются этими фондами для подготовки аспирантов. Но, конечно, совместная ответственность аспиранта и его научного руководителя, зафиксированная в заявке на грант, - это очень важный фактор. Хотелось бы попросить главного редактора Михаила
Борисовича Сапунова подвести некоторые итоги нашей работы.

M.Б. Сапунов: В качестве главного итога нашей работы я бы отметил следующее. Раз уж аспирантура - это образовательная программа, вполне естественно встаёт вопрос об особенностях педагогики высшей школы. Как известно, есть два классических педагогических вопроса: чему учить и как учить. С этими вопросами мы как раз и столкнулись: во-первых, это содержание образовательной программы (учебный предмет) в аспирантуре, во-вторых, специфические требования к компетенциям как преподавателя, ведущего здесь занятия, так и научного руководителя. Подчеркну: это вопросы организации учебного процесса в аспирантуре, т.е. они обращены не к обучающимся, не к результатам их обучения, а к администрации и преподавателям. На мой взгляд, сегодня состоялся разговор именно на эту тему. Кто он - преподаватель аспирантуры? Кто он - научный руководитель? Постановка этих вопросов - серьёзное продвижение по пути осмысления сути новой модели аспирантуры. Их обсуждение, несомненно, приведёт не только к постановке новых проблем, но и наметит новые решения как это и обозначено в названии круглого стола. Если вспомнить содержание состоявшихся в 2014-2018 гг. с участием журнала дискуссий, то надо признать, что сегодня у нас состоялся очень перспективный поворот исследовательского внимания. Пользуясь случаем, приглашаю научно-педагогическое сообщество продолжить разговор об аспирантуре на страницах журнала и в таком ракурсе.

\section{A New Model of Russian Doctoral Education: Problems and Prospects}

Abstract. On November 16, 2018, as a part of its Advanced Training Program, the National Research Lobachevsky State University of Nizhny Novgorod (UNN) hosted a round table organized by the UNN Institute of Postgraduate and Doctoral Studies jointly with the editorial board of the journal "Higher Education in Russia". The topic of the round table discussion was "A New Model of Russian Doctoral Education: Problems and Prospects for Development”. The Program is being implemented in accordance with the UNN's "Roadmap" for 2018 within the framework of the Russian 
Academic Excellence Project (the "5-100" Project). The event was attended by 48 administrative, managerial and academic staff members from 24 cities, representing 37 universities and research organizations of the Russian Federation (including NUST MISIS, National Research University Higher School of Economics, UNN, Tomsk Polytechnic University, Samara National Research University, Plekhanov Russian University of Economics, Belgorod National Research University, Ogarev Mordovia State University, Tyumen National Research University, etc.). Moderators of the round table: Director of the UNN Institute of Postgraduate and Doctoral Studies Prof. B.I. Bednyi and the Chief Editor of the journal «Higher Education in Russia» Prof. M.B. Sapunov.

Keywords: postgraduate studies, academic staff, doctoral education, dissertation, educational standards of postgraduate education, postgraduate education programs, state final certification of postgraduate students

Cite as: Bednyi, B.I., Sapunov, M.B. et al. (2019). [A New Model of Russian Doctoral Education: Problems and Prospects (round table)]. Vysshee obrazovanie $v$ Rossii=Higher Education in Russia. Vol. 28. No. 1. Pp. 130-146 (In Russ., abstract in Eng.)

DOI: https://doi.org/10.31992/0869-3617-2019-28-1-130-146

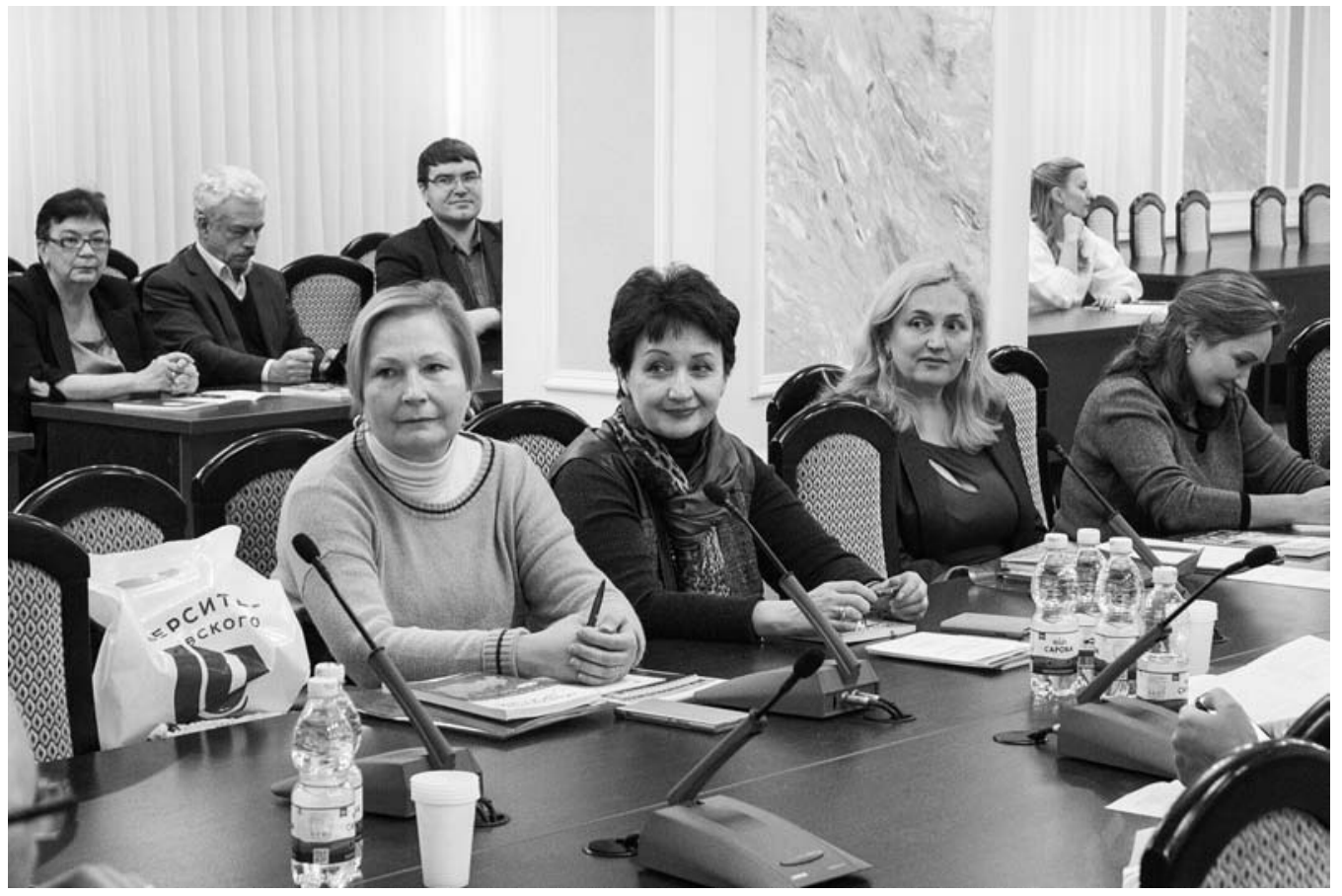

